\title{
Self-care activities, sociodemographic variables, treatment and depressive symptoms among older adults with Diabetes Mellitus
}

\author{
Atividades de autocuidado, variáveis sociodemográficas, tratamento e sintomas depressivos \\ entre idosos com Diabetes Mellitus \\ Actividades de autocuidado, variables sociodemográficas, tratamiento y síntomas depresivos \\ entre adultos mayores con Diabetes Mellitus
}

\section{Fernanda Auxiliadora Trevizani' ORCID: 0000-0003-2840-558X \\ Daniella Tech Doreto' ORCID: 0000-0001-9422-7449 \\ Gabriella Santos Lima' ORCID: 0000-0001-8657-4002 \\ Sueli Marques' \\ ORCID: 0000-0002-4301-087X}

'Universidade de São Paulo. Ribeirão Preto, São Paulo, Brazil.

How to cite this article: Trevizani FA, Doreto DT, Lima GS, Marques S. Self-care activities, sociodemographic variables, treatment and depressive symptoms among older adults with Diabetes Mellitus. Rev Bras Enferm. 2019;72(Suppl 2):22-9. doi: http://dx.doi.org/10.1590/0034-7167-2017-0579

\section{Corresponding Author:}

Fernanda Auxiliadora Trevizani E-mail: fernanda_trevizani@hotmail.com

Submission: 08-18-2017 Approval: 01-10-2019

\section{ABSTRACT}

Objective: to analyze the association between self-care activities of older adults with Type 2 Diabetes Mellitus (DM) and sociodemographic variables, type of treatment and depressive symptoms. Method: inferential and cross-sectional study, with 121 older adults with Type $2 \mathrm{DM}$ in ambulatory care. We used a questionnaire for characterization of sociodemographic and health, questionnaire self-care activities with DM, Mini Mental State Examination and Geriatric Depression Scale. The association of variables was used (Fisher's exact test) and for comparing the means (Student's t-test and analysis of variance). Results: The mean age was 68.1 years, the majority were women (57.2\%), retired (71.9\%) and married (65.3\%). The highest averages were for the activities: "to dry the spaces between the toes, after washing them" and smaller averages for "exercise". Conclusion: In spite of high average for self-care activities, there is a need for enhanced performance and compliance to them.

Descriptors: Aged; Self Care; Diabetes Mellitus; Aging; Nursing.

\section{RESUMO}

Objetivo: Analisar relação entre atividades de autocuidado de idosos com Diabetes Mellitus Tipo 2 (DM) e variáveis sociodemográficas, tipo de tratamento e sintomas depressivos. Método: Estudo inferencial e transversal, com 121 idosos com DM Tipo 2 em atendimento ambulatorial. Utilizaram-se Questionário para caracterização sociodemográfica e de saúde, Questionário Atividades de autocuidado com o DM, Miniexame do Estado Mental e Escala de Depressão Geriátrica. Para associação das variáveis, foi utilizado teste exato de Fisher. Para comparação das médias, foram realizados teste t-Student e análise de variância. Resultados: A média de idade foi 68,1 anos, sendo a maioria mulheres $(57,2 \%)$, aposentados $(71,9 \%)$ e casados $(65,3 \%)$. As maiores médias foram para as atividades "secar os espaços entre os dedos dos pés, depois de lavá-los" e as menores para "prática de atividades físicas". Conclusão: Apesar das médias elevadas para as atividades de autocuidado, observou-se a necessidade de seu melhor desempenho e adesão.

Descritores: Idoso; Autocuidado; Diabetes Mellitus; Envelhecimento; Enfermagem.

\section{RESUMEN}

Objetivo: Analizar la relación entre las actividades de autocuidado de adultos mayores con Diabetes Mellitus Tipo 2 (DM) y las variables sociodemográficas, clase de tratamiento y síntomas depresivos. Método: se trata de un estudio inferencial y transversal realizado entre 121 adultos mayores con DM tipo 2 en atención ambulatoria, desarrollado mediante el Cuestionario para la caracterización sociodemográfica y de salud, el de Actividades de Autocuidado con la DM, el Mini Examen del Estado Mental y la Escala de Depresión Geriátrica. Para asociar las variables se utilizó la Prueba Exacta de Fisher y para comparar los promedios, la Prueba t de Student y el Análisis de varianza. Resultados: la edad promedio era de 68,1 años, la mayoría del sexo femenino $(57,2 \%)$, jubilados $(71,9 \%)$ y casados $(65,3 \%)$. Los promedios más altos apuntaron hacia las actividades:"secar los espacios entre los dedos después de lavarlos" y los más bajos hacia la "práctica de actividades físicas". Conclusión: A pesar de los promedios elevados en las actividades de autocuidado, se nota la necesidad de mejorar el rendimiento y el cumplimiento de las mismas.

Descriptores: Anciano; Autocuidado; Diabetes Mellitus; Envejecimiento; Enfermería. 


\section{INTRODUCTION}

Population aging is a global reality. By the year 2015, the world's older adults population has increased to 900 million and it is expected that by 2050 there will be 2100 million older adults, or $22.0 \%$ of the global population ${ }^{(1)}$.

In this scenario, there is an increase in chronic non-communicable conditions, such as Diabetes Mellitus (DM), which has presented high prevalence due to population aging, greater urbanization, progressive predominance of obesity and sedentary lifestyle, and greater patient survival with this disease. It is estimated that by 2035 the world population with DM should reach 471 million $^{(2)}$. In Brazil, there is also an increase in the number of people diagnosed with DM, affecting more than 14.3 million people ${ }^{(3-4)}$.

Diabetes Mellitus Type 2 (DM2) is characterized by deterioration of beta-pancreatic cell function, resulting in the combination of insulin resistance and inadequate secretory insulin response. It is caused by the interaction of genetic and environmental factors. There are factors that contribute to the development of DM2 such as heredity, age greater than or equal to 45 years, overweight, sedentary lifestyle, hypertension, low HDL coronary disease or elevated triglycerides, use of hyperglycemic drugs (corticosteroids, beta-blockers) and DM gestational age ${ }^{(2)}$.

Among the chronic conditions, the prevalence of neurologicaldegenerative diseases and trends in depression are also highlighted ${ }^{(5)}$. It is estimated that between 15 and $25 \%$ of the general population have depressive symptoms, and in Brazil, between 24 and 30 million people have or will have at least one depressive episode in their lifetime ${ }^{(6)}$. We also emphasize that depression is more common in older adults with DM than in the younger population and its prevalence seems to be increasing with the duration of this disease ${ }^{(7)}$.

Early diagnosis of depression is necessary for adequate glycemic control and prevention of metabolic complications ${ }^{(8)}$.

The existence of chronic conditions implies significant changes in the style and quality of life of the individual. Self-care is one of the aspects to be approached and encouraged in their treatment, since its practice improves health and reduces the cost of treatments ${ }^{(9)}$. The practice of self-care is defined as actions that individuals initiate and execute on their own to maintain life, health and well-being ${ }^{(10)}$.

Self-care practices help in the metabolic control of $\mathrm{DM}^{(11)}$. Therefore, adherence to healthy living habits is essential for the treatment of the disease.

Considering the prevalence of DM in the older adults' population and the degree of complexity of the self-care activities necessary for the adequate control of the disease and the consequent decrease in the occurrence of complications, with a view to the better quality of life for this population sample, one observes the need to evaluate the practice of self-care activities of older adults with diabetes.

\section{OBJECTIVE}

Verify the relationship between self-care activity with DM2 and socio-demographic variables, type of treatment and symptoms of depression in the older adult with DM2 monitored in a
Diabetes Outpatient Clinic of a General Tertiary Hospital in the a city in the State of Sao Paulo

\section{METHOD}

\section{Ethical aspects}

This study was approved by the Research Ethics Committee of the Ribeirão Preto School of Nursing of the University of São Paulo and the Ribeirão Preto Clinic Hospital, through protocol no. 23330013.7.0000.5393. All the participants read and signed the free and informed consent form.

\section{Design, setting and period of study}

This is a quantitative, inferential and cross-sectional study developed at the Diabetes Outpatient Clinic of a General Tertiary Hospital, in a city in the state of Sao Paulo, from February to June 2014.

\section{Sample size, inclusion and exclusion criteria}

The study sample size comprised 121 older adults with DM2, who met the inclusion criteria: age 60 and older, male or female, having a medical diagnosis of DM2, being in care in an outpatient clinic and presenting, at the time of the interview, cognitive conditions to understand and respond the questionnaire (evaluated through the application of Mini-Mental State Examination). For the selection of the sample, we used convenience which is a type of non-probabilistic sampling, in which the probability of an individual being included is not known ${ }^{(12)}$.

\section{Study Protocol}

The data collection was performed, through an interview, using:

- Mini-Mental State Examination (MMSE), validated and modified in Brazil ${ }^{(13)}$, has been used to detect cognitive losses and assess the evolution of diseases and response to treatment. Allowing a total score of 30 points, with higher values indicating better cognitive performance. In this study, we chose to use the cutoff value based on the education levels of the older adults ${ }^{(14)}$.

- Questionnaire for sociodemographic and health characterization of the older adults. It addresses issues related to: social aspects, information on the diagnosis and treatment. It was elaborated by the researcher based on the literature on this topic ${ }^{(15-16)}$ and submitted to face validation. For the validation, the collaboration of experts professionals in the area or subjects from the research area is necessary, reading the instrument and evaluating its content ${ }^{(17)}$. Thus, it was sent for the analysis of three researchers from the areas: geriatrics, gerontology and endocrinology.

- Diabetes Self-Care Activity Questionnaire (SDSCA) - developed to assess compliance to self-care activities of the patient with DM. The translated version, adapted and validated for Brazilian culture from The Summary of Diabetes SelfCare Activities Measure, 
presented internal consistency measured by Cronbach's alpha $0.47^{(18-19)}$. It has 15 items of self-care assessment with DM2 and three items for smoking assessment, distributed in seven dimensions: general diet, specific diet, exercise, blood sugar testing, foot care, medications and smoking. The score of each item ranges from 0 to 7, with zero being the least desirable situation and seven being the most favorable, except for the specific diet dimension that addresses the consumption of high fat and sweet foods, whose values were reversed ${ }^{(19)}$.

- Geriatric Depression Scale (GDE-15) is designed to track mood disorders in older adults, built and reduced ${ }^{(20)}$. For this study, a score greater than or equal to 5 was adopted to determine the presence of depressive symptoms in the older adults studied(21).

\section{Analysis of results and statistics}

For data analysis, a data sheet was prepared in the Microsoft Excel computer program, with double typing and validation of the data. Subsequently, the database was exported to the statistical software SAS $^{\circ} 9.0$, to perform the analyzes.

Fisher's exact test was used to verify associations between the categorical variables. The internal consistency measure for the SDSCA items was evaluated by the Cronbach alpha coefficient, for means comparisons, the t-test was used for two means and the test of Bartlett's homogeneity of variances was applied to evaluate compliance with the assumption of normality ${ }^{(22-23)}$. The level of significance was set at $5 \%$ for all tests.

\section{RESULTS}

As for the sociodemographic characterization of the older adult, the mean age was 68.1 years, the majority (57.2\%) were women; (65.3\%) were married or living with a partner, the average number of years of study was $3.9(\mathrm{SD}=4.3)$. As for the occupation/ profession, most (71.9\%) were retired, and the average family income was $\mathrm{R} \$ 1,885.38$ (Table 1 ).

Regarding the type of treatment adopted for DM2, most of them (79.3\%) used oral antidiabetic (OAD) and insulin, 33.8\% used insulin, 10.9\% used OAD and $67.8 \%$ did not perform exercises. It should be noted that the treatment categories were not exclusive, allowing the participant to indicate more than one from them.

As for the averages of days in the week in which self-care activities were performed, it was observed that the highest averages were for the activities: "to dry the spaces between the toes after washing it" 6.4 ( $S D=1.8)$, and the lowest averages were for activities: "exercising for at least 30 minutes", $1.6(\mathrm{SD}=2.6)$, "specific exercise (swimming, walking)", $1.6(\mathrm{SD}=2.5)$ (Table 2).
Table 1 - Distribution of the older adult with DM2 $(\mathrm{N}=121)$ in outpatient follow-up, according to the variables age, gender, marital status, education, occupation and income, Ribeirão Preto, São Paulo, Brazil, 2014

\begin{tabular}{|c|c|c|c|c|c|}
\hline Variables & $\mathbf{n}$ & $\%$ & Minimum & Maximum & $\begin{array}{l}\text { Mean } \\
\text { (SD)* }\end{array}$ \\
\hline Age & & & 60 & 86 & $68.1(6.2)$ \\
\hline 60 to 69 & 80 & 66.1 & & & \\
\hline 70 to 79 & 33 & 27.2 & & & \\
\hline 80 and + & 8 & 6.6 & & & \\
\hline \multicolumn{6}{|l|}{ Gender } \\
\hline Female & 69 & 57.2 & & & \\
\hline Male & 52 & 42.9 & & & \\
\hline \multicolumn{6}{|l|}{ Marital status } \\
\hline Single & 6 & 5.0 & & & \\
\hline Married/live companion & 79 & 65.3 & & & \\
\hline Widow & 29 & 24.0 & & & \\
\hline Divorced/separated & 7 & 5.8 & & & \\
\hline Education & & & 0.0 & 20.0 & $3.9(4.3)$ \\
\hline Illiterate & 39 & 32.2 & & & \\
\hline Read and write informally & 8 & 6.6 & & & \\
\hline Incomplete first degree & 32 & 26.5 & & & \\
\hline Complete first degree & 22 & 18.2 & & & \\
\hline Incomplete second degree & 6 & 5.0 & & & \\
\hline Complete second degree & 0 & 0.0 & & & \\
\hline Complete third degree & 5 & 4.1 & & & \\
\hline Others & 9 & 7.4 & & & \\
\hline \multicolumn{6}{|l|}{ Profession / Occupation } \\
\hline Retired & 87 & 71.9 & & & \\
\hline Pensioner & 16 & 13.2 & & & \\
\hline Unemployed & 0 & 0 & & & \\
\hline Home & 7 & 5.8 & & & \\
\hline Self Employed & 4 & 3.3 & & & \\
\hline Others & 7 & 5.8 & & & \\
\hline Family income & & & 700.00 & $6,000.00$ & $\begin{array}{c}1,855.38 \\
(1,034.72)\end{array}$ \\
\hline Total & 121 & 100 & & & \\
\hline
\end{tabular}

Table 2 - Descriptive statistics of the items of the Diabetes Self-Care Activities Questionnaire, for the older adult with DM2 ( $N=121)$, outpatient follow-up, Ribeirão Preto, São Paulo, Brazil, 2014

\begin{tabular}{lcc}
\hline SDSCA Items & Mean & SD (DP) \\
\hline 1. Follow a healthy diet & 4.9 & 2.5 \\
2. Follow the food orientation given by a professional & 3.4 & 3.1 \\
3. Ingest five or more fruit and/or vegetable & 4.6 & 2.6 \\
4. Eat red meat and/or whole milk products. & 4.9 & 2.6 \\
5. Ingestion of sweets & 0.8 & 1.5 \\
6. Exercising for at least 30 minutes & 1.6 & 2.6 \\
7. Specific exercise (swimming, walking) & 1.6 & 2.5 \\
8. Blood sugar testing & 5.4 & 2.5 \\
9. Evaluate blood sugar the recommended number of times & 5.5 & 2.5 \\
10. Foot care & 4.8 & 3.0 \\
11. Examine inside the shoes before putting them on. & 4.2 & 3.2 \\
12. Dry the spaces between the toes, after washing them & 6.4 & 1.8 \\
13. Take insulin injections as recommended & 6.1 & 2.3 \\
14. Take the indicated number of diabetes pills & 4.5 & 3.3 \\
\hline
\end{tabular}

Note: $S D S C A=$ Diabetes Self-Care Activities Questionnaire.

Regarding smoking, $51.2 \%$ of the older adult reported they had never smoked and $5.8 \%$ reported smoking, with a mean of 0.3 cigarettes/day.

Regarding depressive symptoms, $55.4 \%$ presented the symptoms and $44.6 \%$ did not.

In the comparison between the means for the dimensions of the SDSCA and the variables marital status, education and income of 
the studied older adult. There was statistical significance between the variable marital status and the blood sugar testing $(p=0.03)$, showing lower mean days in the week for the unmarried $3.3(\mathrm{SD}=3.3)$ and for the divorced/separated $4.0(\mathrm{SD}=2.4)$. It was also observed a statistical significance between the income variable and the specific feeding dimension $(p=0.00)$, showing a lower average of $3.8(S D=1.4)$ for the older adults who were in the $1^{\text {st }}$ tertile of income, that is, they had income of up to R\$ 1,300.00 (Table 3).

In the comparison between the means for the dimensions of the SDSCA and the variable types of treatment of the participants of this study, it was observed that there was statistical significance between treatment with diet and foot care dimension $(p=0.03)$; treatment with insulin and the dimensions of blood sugar testing $(p=0.01)$ and medication $(p=0.00)$; treatment with OAD and insulin and the dimensions of blood sugar testing $(p=0.01)$ and medication $(p=$ $0.00) ;(p=0.01)$, blood sugar testing $(p=0.00)$ and medication $(p=$ $0.01)$ and exercise with the exercise dimension $(p=0.00)$ (Table 4).

As for the comparison between the means for the dimensions of the SDSCA and the variables with and without depressive symptoms, it was observed that there was no statistically significant difference between the means of days in the week for each of the dimensions of the SDSCA and the presence or absence of depressive symptoms among the older adult studied. The mean number of days in the exercise dimension is lower, both for the older adult with symptoms of depression $2.0(\mathrm{SD}=2.8)$ and for those without symptoms $1.1(\mathrm{SD}=2.1)$ (Table 5).

Table 3 - Descriptive statistics and comparison test between the means for the dimensions of the Diabetes Self-Care Activities Questionnaire and the variables marital status, education and income, of the older adults ( $\mathrm{N}=121)$ in outpatient follow-up, Ribeirão Preto, São Paulo, Brazil, 2014

\begin{tabular}{|c|c|c|c|c|c|c|c|c|c|c|c|c|}
\hline \multirow{3}{*}{ Variable } & \multicolumn{12}{|c|}{ Dimensions of the Diabetes Self-Care Activities Questionnaire } \\
\hline & \multicolumn{2}{|c|}{ General diet } & \multicolumn{2}{|c|}{ Specific diet } & \multicolumn{2}{|c|}{ Exercise } & \multicolumn{2}{|c|}{$\begin{array}{c}\text { Blood sugar } \\
\text { testing }\end{array}$} & \multicolumn{2}{|c|}{ Foot care } & \multicolumn{2}{|c|}{ Medication } \\
\hline & $\begin{array}{l}\text { Mean } \\
\text { (SD) }\end{array}$ & $\underset{\text { value }}{p}$ & $\begin{array}{l}\text { Mean } \\
\text { (SD) }\end{array}$ & $\underset{\text { value }}{p}$ & $\begin{array}{l}\text { Mean } \\
\text { (SD) }\end{array}$ & $\underset{\text { value }}{p}$ & $\begin{array}{l}\text { Mean } \\
\text { (SD) }\end{array}$ & $\underset{\text { value }}{p}$ & $\begin{array}{c}\text { Mean } \\
\text { (SD) }\end{array}$ & $\underset{\text { value }}{p}$ & $\begin{array}{c}\text { Mean } \\
\text { (SD) }\end{array}$ & $\begin{array}{c}p \\
\text { value }\end{array}$ \\
\hline \multicolumn{13}{|l|}{ Marital status* } \\
\hline Single & $4.6(3.1)$ & & $4.0(1.0)$ & & $1.1(2.8)$ & & $3.3(3.3)$ & & $4.6(2.0)$ & & $5.8(1.2)$ & \\
\hline Married & $4.3(2.4)$ & 0.22 & $4.2(1.3)$ & 0.84 & $1.5(2.4)$ & 0.42 & $5.5(2.3)$ & 0.03 & $5.4(1.9)$ & 0.23 & $5.9(1.9)$ & 0.70 \\
\hline Widow & $3.3(2.5)$ & & $4.4(1.5)$ & & $1.4(2.5)$ & & $5.9(2.1)$ & & $4.6(2.2)$ & & $5.6(1.1)$ & \\
\hline Divorced/Separated & $4.7(2.4)$ & & $4.3(1.4)$ & & $3.0(2.8)$ & & $4.0(2.4)$ & & $5.2(2.1)$ & & $6.0(1.2)$ & \\
\hline \multicolumn{13}{|l|}{ Years of study } \\
\hline None & $4.2(2.5)$ & & $4.2(1.3)$ & & $1.9(2.8)$ & & $5.3(2.4)$ & & $5.0(2.2)$ & & $5.6(1.1)$ & \\
\hline 1 to 4 years & $3.9(2.5)$ & 0.51 & $4.1(1.4)$ & 0.82 & $1.0(2.1)$ & 0.37 & $5.6(2.4)$ & 0.74 & $5.2(1.9)$ & 0.59 & $5.9(1.2)$ & 0.47 \\
\hline 5 to 8 years & $4.7(2.5)$ & & $4.4(1.6)$ & & $2.1(2.8)$ & & $4.9(2.2)$ & & $5.0(1.7)$ & & $6.1(1.1)$ & \\
\hline 9 to 11 years & $2.9(2.5)$ & & $4.5(1.5)$ & & $1.8(3.1)$ & & $5.0(3.4)$ & & $4.3(2.8)$ & & $5.3(1.1)$ & \\
\hline 12 and over & $4.6(1.9)$ & & $4.6(1.0)$ & & $1.0(1.5)$ & & $6.1(1.4)$ & & $6.0(2.2)$ & & $5.9(1.2)$ & \\
\hline \multicolumn{13}{|l|}{ Income (tercile)* } \\
\hline 1 to $\mathrm{R} \$ 1,399.99$ & $4.1(2.4)$ & & $3.8(1.4)$ & & $1.1(2.2)$ & & $5.7(2.3)$ & & $4.9(2.1)$ & & $5.7(1.1)$ & \\
\hline $\mathrm{R} \$ 1,400.00$ to $2,099.99$ & $4.2(2.4)$ & 0.94 & $4.0(1.3)$ & 0.00 & $2.0(2.7)$ & 0.26 & $5.4(2.5)$ & 0.66 & $5.3(1.9)$ & 0.74 & $5.9(1.2)$ & 0.77 \\
\hline $\mathrm{R} \$ 2,100.00$ & $4.0(2.6)$ & & $4.9(1.2)$ & & $1.4(2.4)$ & & $5.2(5.3)$ & & $5.1(2.2)$ & & $5.8(1.1)$ & \\
\hline
\end{tabular}

Note: * Test of comparison of means by analysis of variance, significance value $p<0.05$.

Table 4 - Descriptive statistics and comparison test between the means for the dimensions of the Diabetes Self-Care Activity Questionnaire and the type of treatment of the older adult in an outpatient follow-up ( $N=121)$, Ribeirão Preto, São Paulo, Brazil, 2014

\begin{tabular}{|c|c|c|c|c|c|c|c|c|c|c|c|c|c|}
\hline \multirow[b]{3}{*}{ Type of treatment } & \multirow[b]{3}{*}{$\mathbf{n}$} & \multicolumn{12}{|c|}{ Dimensions of the Diabetes Self-Care Activities Questionnaire } \\
\hline & & \multicolumn{2}{|c|}{ General diet } & \multicolumn{2}{|c|}{ Specific diet } & \multicolumn{2}{|c|}{ Exercise } & \multicolumn{2}{|c|}{$\begin{array}{c}\text { Blood sugar } \\
\text { testing }\end{array}$} & \multicolumn{2}{|c|}{ Foot care } & \multicolumn{2}{|c|}{ Medication } \\
\hline & & $\begin{array}{l}\text { Mean } \\
\text { (SD) }\end{array}$ & $\begin{array}{c}p \\
\text { value }\end{array}$ & $\begin{array}{l}\text { Mean } \\
\text { (SD) }\end{array}$ & $\begin{array}{c}p \\
\text { value }\end{array}$ & $\begin{array}{l}\text { Mean } \\
\text { (SD) }\end{array}$ & $\begin{array}{c}p \\
\text { value }\end{array}$ & $\begin{array}{l}\text { Mean } \\
\text { (SD) }\end{array}$ & $\begin{array}{c}p \\
\text { value }\end{array}$ & $\begin{array}{l}\text { Mean } \\
\text { (SD) }\end{array}$ & $\begin{array}{c}p \\
\text { value }\end{array}$ & $\begin{array}{l}\text { Mean } \\
\text { (SD) }\end{array}$ & $\begin{array}{c}p \\
\text { value }\end{array}$ \\
\hline \multicolumn{14}{|l|}{ Diet } \\
\hline No & (25) & $0.7(1.0)$ & 1.00 & $4.2(1.2)$ & 0.48 & $1.8(2.6)$ & 0.29 & $4.8(2.8)$ & 0.06 & $4.4(2.3)$ & 0.03 & $5.7(1.1)$ & 0.37 \\
\hline Yes & (96) & $5.0(1.9)$ & & $4.2(1.4)$ & & $1.4(2.5)$ & & $5.6(2.2)$ & & $5.3(1.9)$ & & $5.8(1.1)$ & \\
\hline \multicolumn{14}{|l|}{ Insulin } \\
\hline No & (80) & $4.1(2.5)$ & 0.49 & $4.2(1.4)$ & 0.43 & $1.7(2.5)$ & 0.18 & $5.1(2.5)$ & 0.01 & $5.2(2.0)$ & 0.20 & $6.4(0.9)$ & 0.00 \\
\hline Yes & (41) & $4.1(2.0)$ & & $4.3(1.3)$ & & $1.2(2.4)$ & & $6.1(1.7)$ & & $5.0(2.4)$ & & $4.6(0.1)$ & \\
\hline \multicolumn{14}{|l|}{$\begin{array}{l}\text { Association } \\
\text { (OAD+insulin) }\end{array}$} \\
\hline No & (54) & $3.7(2.4)$ & 0.09 & $4.2(1.3)$ & 0.47 & $1.5(2.6)$ & 0.46 & $4.8(2.7)$ & 0.01 & $4.9(2.2)$ & 0.20 & $4.6(0.1)$ & 0.00 \\
\hline Yes & (67) & $4.3(2.4)$ & & $4.2(1.4)$ & & $1.5(2.4)$ & & $5.9(1.9)$ & & $5.2(1.9)$ & & $6.8(0.6)$ & \\
\hline \multicolumn{14}{|l|}{ Oral anti-diabets } \\
\hline No & (108) & $4.2(2.4)$ & 0.01 & $4.2(1.4)$ & 0.44 & $1.4(2.4)$ & 0.10 & $6.0(1.8)$ & 0.00 & $5.1(2.0)$ & 0.32 & $5.9(1.1)$ & 0.00 \\
\hline Yes & (13) & $2.6(2.7)$ & & $4.2(1.2)$ & & $2.3(3.1)$ & & $1(1.5)$ & & $4.8(2.4)$ & & $4.6(0.0)$ & \\
\hline \multicolumn{14}{|l|}{ Exercise } \\
\hline No & (82) & $3.9(2.4)$ & 0.06 & $4.3(1.4)$ & 0.49 & $0.1(0.9)$ & 0.00 & $5.3(2.4)$ & 0.35 & $4.9(2.1)$ & 0.06 & $5.7(1.1)$ & 0.20 \\
\hline Yes & (39) & $4.5(2.4)$ & & $4.3(1.4)$ & & $4.3(2.2)$ & & $5.6(2.1)$ & & 5.5(1.9) & & $5.9(1.1)$ & \\
\hline
\end{tabular}

Note: Student $t$ test for comparison of means, significance value of $p<0,05$. 
Table 5 - Descriptive statistics and comparison test between the means for the dimensions of the Self-Care Activities Questionnaire with Diabetes and the variables with and without depressive symptoms, in an outpatient follow-up ( $n=121)$, Ribeirão Preto, São Paulo, Brazil, 2014

\begin{tabular}{lccc}
\hline $\begin{array}{l}\text { Dimensions - } \\
\text { SDSCA }\end{array}$ & $\begin{array}{c}\text { With depressive } \\
\text { symptoms Mean } \\
\text { (SD) }\end{array}$ & $\begin{array}{c}\text { Without depressive } \\
\text { symptoms Mean } \\
\text { (SD) }\end{array}$ & $\begin{array}{c}\boldsymbol{p} \\
\text { value }\end{array}$ \\
\hline General diet & $4.1(2.4)$ & $4.0(2.5)$ & 0.43 \\
Specific diet & $4.3(1.4)$ & $4.2(1.3)$ & 0.26 \\
Exercise & $2.0(2.8)$ & $1.1(2.1)$ & 0.96 \\
Blood sugar testing & $5.2(2.4)$ & $5.6(2.3)$ & 0.20 \\
Foot care & $4.9(2.3)$ & $5.3(1.8)$ & 0.16 \\
Medication & $5.7(1.1)$ & $5.9(1.1)$ & 0.10 \\
\hline
\end{tabular}

Note: Student t test comparison, significance value $p<0.05$.

\section{DISCUSSION}

It was observed that the sample consisted of younger individuals, with a mean age of 68.1 years, most of them were women, married/living with partner and retired, results similar to those of others studies ${ }^{(24-25)}$.

In this study, in relation to the type of treatment performed for the control of DM2, we highlight the diet and the association of $\mathrm{OAD}$ and insulin. Similar data were found in the study with older adults of both genders and with DM2, living in the city of Campinas, where the main strategies used to control DM2 were diet and $\mathrm{OAD}$ and insulin ${ }^{(26)}$. The treatment for $\mathrm{DM} 2$ with drugs seems to be more frequently performed by people with the disease, as they do not need to change their life habits. However, studies have shown that several factors may influence medication compliance, such as age, number of medications, time of diagnosis of the disease, psychological aspects, cost of treatment, symptomatic improvement, confidence in the prescriber, good communication with the prescriber and the family ${ }^{(27-28)}$. It was observed that treatments such as the practice of exercise and the use of OAD alone were less cited, which was also found in another study ${ }^{(25)}$. It should be considered that the sample consisted of older adults, a fact that may have contributed to the low practice of exercise, due to the limitations inherent in aging.

Regarding the analysis of averages of days in the week for the self-care activities, the item "dry the spaces between the toes after washing them", in this study, obtained the highest mean. Other studies that aimed to evaluate the self-care activities of adults with $\mathrm{DM} 2$, in which the instrument used for the evaluation was the SDSCA, found lower means ${ }^{(25,29)}$. The periodic examination of the feet allows the prevention of diabetic foot complications ${ }^{(30)}$.

The second highest average among the self-care activities of older adults with DM2 was for the item "taking insulin injections as recommended". Other studies showed close means ${ }^{(25,29)}$. This event is probably related to the belief that the medication has a better glycemic control than food and exercise. In addition, patients are more likely to adhere to medication than to changes in their lifestyle, which would require a change in behavior.

The third highest average was "evaluation of blood sugar the recommended number of times". Finding is similar to another study with a mean of 5.8 days/week ${ }^{(29)}$. The self-monitoring of blood glucose is considered important for intervention in DM2 for determining guidelines for treatment based on the results obtained, besides allowing the review and maintenance of treatment ${ }^{(2)}$.

Regarding the lower means of self-care activities, the most important is exercise "exercising for at least 30 minutes", "specific exercise (swimming and walking)", given a similar study that found an average of 1.5 day/week ${ }^{(26)}$.

Another relevant self-care activity practice is food related. A similar study ${ }^{(29)}$ found mean above this research. For the prevention, treatment and control of DM2, a healthy diet is essential and its main objective is to ensure a balance between food intake and insulin ${ }^{(8)}$.

Reflections are necessary, since possible contradictions may be related to the results obtained in this study, since the average days/week of the item "follow a healthy diet" was higher than the average of the item "follow the food orientation given by a professional", in addition to what most older adults mentioned as one of the dietary treatments. The perception that older adult respondents have a healthy diet may not represent adequate nutritional compositions. In this sense, in the accomplishment of dietary food planning, it is essential to advise the family and the older adult, so that a reorganization in the family dynamics occurs, so that all the members rethink their food in order to make it healthier, in the process of adapting the person with DM.

Regarding sweetness intake, the mean found in this study was low. Another study found higher means, 1.53 days/week ${ }^{(31)}$. During the interview, several older adults reported eating sweets and, in the instrument used, there are no items that address the type of sweets consumed, but the low weekly consumption of sweets indicates an understanding of the guidelines and need for healthier life habits for DM2 control.

Regarding smoking and mean number of cigarettes consumed, similar results were found in studies: performed with adults and older adults with DM2, living in the city of Viçosa-MG ${ }^{(32)}$ and the other with adults of both genders, with DM2 attended in two Basic Health Units in a city in the State of Sao Paulo ${ }^{(29)}$. Cigarette smoking impairs glycemic and metabolic control, in addition to contributing to an increase in the mortality rate due to cardiovascular diseases caused by diabetes ${ }^{(2)}$.

Regarding depressive symptoms, the data found in this study corroborate another study that verified the prevalence of depressive symptoms between senescent ones ${ }^{(33)}$. The prevalence of the presence of depressive symptoms presented by the older adult studied does not seem to have hindered the practice of self-care activities by them. On the other hand, a study with adults with DM2 showed that the presence of depressive symptoms contributed to lower adherence to DM2 treatment and poor metabolic control (34).

The analysis of the comparison between the means of the dimensions of the SDSCA and the socio-demographic variables showed that, regarding marital status and blood sugar testing, it was observed that the married or living with a partner adult monitored blood glucose more than the divorced/separated. It is believed that family support provides the treatment for DM2 (35). As for widowers, they are supposed to cohabit with other family members who also provide support and encouragement for self-care. In relation to income, there was a lower average of days in the week to follow a specific diet, for the older adult who had monthly income of up to $\mathrm{R} \$ 1,300.00$. However, in a study performed with adults with $\mathrm{DM} 2$, there was no association 
between treatment adherence and the family income variable ${ }^{(36)}$. The most appropriate food plan involves a number of factors, including socioeconomic variables ${ }^{(2,8)}$.

Regarding the comparison between the means of the dimensions of the SDSCA and the types of treatment, it was observed that the older adult who indicated the treatment with the diet obtained a greater average of days with the foot care. In a study performed with people with DM2 and complications in lower limbs, it was shown that self-care with food was close to desirable, but foot care was low ${ }^{(29)}$.

Regarding older adults who were taking insulin, they had a longer mean in the glycemic monitoring dimension and in the medication dimension. A study that evaluated the experiences of patients with blood glucose monitoring showed that the dimension of self-care promotes benefits and contributes to the choice of decisions for the control of the disease ${ }^{(37)}$. It is important to note that capillary glucose monitoring is indicated for all patients treated with insulin or oral antidiabetic agents ${ }^{(2)}$. A cross-sectional study verified the adherence of people with DM2 to the drug treatment. High adherence was identified by the sample in question, but no statistical significance was observed for the different types of treatment (insulin only, oral antidiabetic only and associations). The authors point out that there is no consensus in the definition on the drug adherence of patients with $\mathrm{DM} 2^{(38)}$.

As for the older adults who underwent OAD and insulin treatment, there were higher averages for the glycemic monitoring dimensions, another study ${ }^{(25)}$ presented similar results. On the other hand, it had divergent results regarding OAD and insulin treatment and the dimension medication and OAD treatment and the dimensions general diet, blood glucose monitoring and medication $^{(25)}$. However, it is believed that people with DM2 more frequently perform the self-care activity related to medication use, regardless of the type of drug prescribed ${ }^{(25)}$. Compared to treatment with OAD and size general nutrition, it was found that older adults who were treated with OAD had higher means in the dimension supply voltage, a situation which meets the literature, wherein compliant patients with OAD tend to follow a regular diet, and maintain control over the disease ${ }^{(39-40)}$.

Regarding the findings related to exercise, it is relevant to summarize some aspects that involve this self-care, due to its low adherence. Exercise reduces insulin resistance, facilitating the peripheral use of glucose, with consequent improvement of glycemic control, providing a reduction in body weight, preventing microvascular and macrovascular complications, and corroborating the proper management of $\mathrm{DM} 2^{(2)}$.

In the outpatient clinic of this study, people with a diagnosis of DM2 are offered health education activities collectively or individually, with the purpose of preventing complications of the disease, healing doubts about drug treatment and insulin therapy, stimulating the performance of exercise and a healthy diet and promoting the quality of life of these patients. In view of this, the older adults in this study may have benefited, since the participation of these activities, in an effective way, suggesting a greater stimulus for self-care, minimizing the influence of depressive symptoms in their daily life with chronic illness.

Within the context of chronic diseases, it is worth mentioning the $\mathrm{DM} 2$, whose attention requires the involvement of health professionals, patients and family members, for a systematized follow-up, focusing on several aspects of health care. The treatment for DM2 has specificities and peculiarities that make the patient the main responsible for the management of the disease, through the activities of self-care, which should be conceived in the supported perspective and not in the mere transference of responsibility to the individuals living with the disease and their families.

\section{Study Limitations}

Regarding the limitations of this study, it is emphasized that the presented results are peculiar to the sample studied here, so generalizations must be viewed with caution, to avoid misunderstandings. In addition, because it is a cross-sectional study, the causality of the factors studied cannot be determined.

\section{Contributions to the area of nursing, health or public policy}

It was observed that despite the high means of days in the week for certain self-care activities, there are still gaps in the performance of activities relevant to self-care with DM2, being inevitable, orientated towards lifestyle change and the development of abilities that favor and empower the independence and autonomy of the older adult for the performance of the self-care.

\section{CONCLUSION}

The results of this study allowed us to observe that the sample consisted of younger adults, with predominance of women, married/living with partners and retirees. Regarding the type of treatment, the most important of the self-care activities were: "dry the spaces between the toes, after washing them" and the least important were physical activities. With regard to smoking, little more than half reported that they had never smoked. Despite the prevalence of depressive symptoms, these did not influence the practice of self-care activities. Married or living with a partner adults monitored blood glucose more than divorced/ separated individuals. As for income, there was a lower average of days in the week to follow a specific diet for the older adult who had monthly income of up to $\mathrm{R} \$ 1,300.00$. It was observed that the older adult who indicated the treatment with diet obtained a greater average of days with foot care. In relation to the older adults who were taking insulin, they had a longer mean in the glycemic monitoring dimension than in the medication dimension.

However, despite the high mean of days in the week for certain self-care activities, the need for better adherence to self-care activities with DM2 was reintroduced.

In this way, relevant investments by health professionals is fundamental, especially by nurses, in the elaboration of planned educational actions directed to self-care with diabetes, considering age, level of education, purchasing power, marital status, physical and functional limitations, impairments in cognition, mental health, among others, involving the older adult, family, community and healthcare services of the health care network, highlighting the teams working in primary care, thus valuing collaborative and continuous practices. 


\section{REFERENCES}

1. World Health Organization-WHO. Multisectoral action for a life course approach to healthy ageing: draft global strategy and plan of action on ageing and health. 69 World Health Assembly [Internet]. Geneva:WHO; 2016 [cited 2017 Jul 14]. Available from: http://apps.who.int/gb/ ebwha/pdf_files/WHA69/A69_17-en.pdf.

2. Sociedade Brasileira de Diabetes-SBD. Diretrizes da Sociedade Brasileira de Diabetes (2015-2016) [Internet]. São Paulo: A.C. Farmacêutica; 2016 [cited 2017 Jul 14]. Available from: http://www.diabetes.org.br/profissionais/images/docs/DIRETRIZES-SBD-2015-2016.pdf.

3. International Diabetes Federation-IDF. Atlas. 8th ed. [Internet]. Brussels: International Diabetes Federation; 2017. [cited 2018 Jun 01]. Available from: https://www.idf.org/e-library/epidemiology-research/diabetes-atlas.html.

4. Brito GMG, Gois CFL, Zanetti ML, Resende GGS, Silva JRS. Quality of life, knowledge and attitude after educational program for diabetes. Acta Paul Enferm. 2016;29(3):298-306. doi: 10.1590/1982-0194201600042

5. Santos $C A$, Ribeiro AQ, Rosa COB, Ribeiro RCL. Depression, cognitive deficit and factors associated with malnutrition in elderly people with cancer. Ciênc Saúde Colet. 2015;20(3):760-751. doi: 10.1590/1413-81232015203.06252014

6. Öztürk ZA, Yesil Y, Kuyumcu ME, Savas E, Uygun Ö, Sayıner ZA, et. al. Association of depression and sleep quality with complications of type 2 diabetes in geriatric patients. Aging Clin Exp. Res. 2015; 27(4):533-538. doi: 10.1007/s40520-014-0293-0

7. Ludman EJ, Peterson D, Katon WJ, Lin EH, Von Korff M, Ciechanowski P, et al. Improving confidence for self care in patients with depression and chronic illnesses. Behav Med. 2013; 39(1):1-6. doi: 10.1080/08964289.2012.708682

8. American Diabetes Association-ADA. Standards of medical care in diabetes: 2016 (Supplement 1) [Internet]. Arlington (VA): ADA; 2016 [cited 2016 Jun 12]. Available from: http://www.healthmonix.com/ADAWebcastSOC2016/common/files/2016SofC.pdf

9. Orem DE. Nursing: concepts of practice. 6th ed. St. Louis (MO): Mosby Inc; 2001

10. Orem DE, Taylor SG. Reflections on nursing practice science: the nature, the structure, and the foundation of nursing sciences. Nurs Sci Q. 2011;24(1):35-41. doi: 10.1177/0894318410389061

11. Cortez DN, Macedo MML, Souza DAS, Santos JC, Afonso GS, Reis IA, et al. Evaluating the effectiveness of an empowerment program for selfcare in type 2 diabetes: a cluster randomized trial. BMC Public Health. 2017;17:41. doi: 10.1186/s12889-016-3937-5

12. Pagano M, Gauvreau K. Princípios de Bioestatística. 2a ed. São Paulo: Cengage Learning; 2006.

13. Bertolucci PHF, Brucki SMD, Campacci SR, Juliano Y. O mini-exame do estado mental em uma população geral: impacto da escolaridade. Arq Neuropsiquiatr [Internet]. 1994 [cited 2015 Dec 10]; 52(1):1-7. Available from: http://www.scielo.br/pdf/anp/v52n1/01.pdf

14. Brucki SMD, Nitrini R, Caramelli P, Bertolucci PHF, Okamoto IH. Sugestões para o uso do mini-exame do estado mental no Brasil. Arq Neuropsiquiatr [Internet]. 2003 [cited 2015 Dec 10]; 61(3-B):777-81. Available from: http://www.scielo.br/pdf/anp/v61n3B/17294.pdf

15. Stacciarini TSG, Pace AE, Haas VJ. Insulin self-administration technique with disposable syringe among patients with Diabetes Mellitus followed by the family health strategy. Rev Latino-Am Enfermagem. 2009;17(4):474-80. doi: 10.1590/S0104-11692009000400007

16. Villas Boas LCG, Foss MC, Foss-Freitas MC, Torres HC, Monteiro LZ, Pace AE. Adesão à dieta e ao exercício físico das pessoas com Diabetes Mellitus. Texto Contexto Enferm [Internet]. 2011 [cited 2017 Mar 13];20(2):272-9. Available from: http://www.scielo.br/pdf/tce/v20n2/ a08v20n2.pdf

17. Lobiondo-Wood G, Haber J. Pesquisa em enfermagem: métodos, avaliação, crítica e utilização. 4a ed. Rio de Janeiro: Guanabara-Koogan; 2001.

18. Toobert DJ, Hampson SE, Glasgow RE. The summary of diabetes selfcare activities measure: results from 7 studies and a revised scale. Diabetes Care [Internet]. 2000 [cited 2017 Mar 13];23(7):943-50. Available from: http://care.diabetesjournals.org/content/diacare/23/7/943.full.pdf

19. Michels MJ, Coral MHC, Sakae TM, Damas TB, Furlanetto LM. Questionário de Atividades de Autocuidado com o Diabetes: tradução, adaptação e avaliação das propriedades psicométricas. Arq Bras Endocrinol Metab 2010;54(3):644-51. doi: 10.1590/ S0004-27302010000700009

20. Yesavage JA, Brink TL, Rose TL, Lum O, Huang V, Adey M, et al. Development and validation of a geriatric depression screening scale: a preliminary report. J Psychiat Res. 1982-1983; 17(1):37-49.

21. Almeida OP, Almeida SA. Confiabilidade da versão brasileira da Escala de Depressão em Geriatria (GDS) versão reduzida. Arq Neuropsiquiatr[Internet]. 1999 [cited 2015 Dec 20];57(2-B):421-26. Available from: http://www.scielo.br/pdf/anp/v57n2B/1446.pdf

22. Berquó ES, Souza JMP, Gotlieb SD. Bioestatística. São Paulo: EPU; 1981

23. Snedecor GW, Cochran WG. Statistical Methods. 8th ed. Ames (IA): lowa State University Press; 1989.

24. Borba AKOT, Marques APO, Leal MCC, Ramos RSPS, Guerra ACCG, Caldas TM. Adherence to drug therapy in diabetic elderly. Rev RENE[Internet]. 2013 [cited 2017 Mar 15];14(2):394-404. Available from: http://periodicos.ufc.br/rene/article/view/3400/2636

25. Coelho ACM, Villas Boas LCG, Gomides DS, Foss-Freitas C, Pace AE. Self-care activities and their relationship to metabolic and clinical control of people with Diabetes Mellitus. Texto Contexto Enferm. 2015;24(3):697-705. doi: 10.1590/0104-07072015000660014

26. Prado MAMB, Francisco PMSB, Barros MBA. Diabetes in the elderly: drug use and the risk of drug interaction. Ciênc Saúde Colet. 2016;21(11):3447-58. doi: 10.1590/1413-812320152111.24462015 
27. Carvalho CV, Rocha LP, Carvalho DP, Silva BT, Oliveira SM, Silveira RB. Adherence of people with type II Diabetes Mellitus to drug treatment. Rev Enferm UFPE. 2017;11(9):3402-9. doi: 10.5205/reuol.11088-99027-5-ED.1109201711

28. Souza MSF, Kopittke L. Adesão ao tratamento com psicofármacos: fatores de proteção e motivos de não adesão ao tratamento farmacológico. Rev APS[Internet]. 2016 [cited 2018 Oct 03];19(3):361-9. Available from: http://ojs2.ufjf.emnuvens.com.br/aps/article/ view/15497/8139

29. Gomides DS, Villas-Boas LCG, Coelho ACM, Pace AE. Self-care of people with diabetes mellitus who have lower limb complications. Acta Paul Enferm. 2013;26(3):289-93. doi: 10.1590/S0103-21002013000300014.

30. Oliveira PS, Bezerra EP, Andrade LL, Gomes PLF, Soares MJGO, Costa MML. Practice nurse family health strategy in the prevention of diabetic foot. Rev Pesqui: Cuid Fundam. 2016;8(3):4841-9. doi: 10.9789/2175-5361.2016.v8i3.4841-4849

31. Veras VS, Santos MA, Rodrigues FFL, Arrelias CCA, Pedersoli TAM, Zanetti ML. Self care among patients enrolled in a self-monitoring blood glucose program. Rev Gaúcha Enferm. 2014;35(4):42-8. doi: 10.1590/1983-1447.2014.04.47820

32. Vitoi NC, Fogal AS, Nascimento CM, Franceschini SCC, Ribeiro AQ. Prevalence and associated factors of diabetes in the elderly population in Viçosa, Minas Gerais, Brazil. Rev Bras Epidemiol. 2015;18(4):953-65. doi: 10.1590/1980-5497201500040022

33. Frade J, Barbosa P, Cardoso S, Nunes C. Depression in the elderly: symptoms in institutionalised and non-institutionalised individuals. Rev Enf Ref. 2015;IV(4):41-48. doi: 10.12707/RIV14030

34. Coelho MP, Chianca TCM, Soares SM. Depression in diabetic people - unveiling the hidden enemy. REME Rev Min Enferm. 2013;17(4):782-91 . doi: $10.5935 / 1415-2762.20130057$

35. Sérvan PR. Obesity and diabetes. Nutr Hosp. [Internet]. 2013 [cited 2017 Mar 18];28(Supl. 5):138-43. Available from: http://www. nutricionhospitalaria.com/pdf/6929.pdf

36. Faria HTG, Rodrigues FFL, Zanetti ML, Araújo MFM, Damasceno MMC. Factors associated with adherence to treatment of patients with diabetes mellitus. Acta Paul Enferm. 2013; 26(3):231-7. doi: 10.1590/S0103-21002013000300005

37. Dlugasch LB, Ugarriza DN. Self-monitoring of blood glucose experiences of adults with type 2 diabetes. J Am Assoc Nurse Pract. 2014;26(6):323-9. doi: 10.1002/2327-6924.12042

38. Villas Boas LCG, Foss-Freitas MC, Pace AE. Adesão de pessoas com diabetes mellitus tipo 2 ao tratamento medicamentoso. Rev Bras Enferm. 2014;67(2):268-73. doi: 10.5935/0034-7167.20140036

39. Arrelias CCA, Faria HTG, Teixeira CRS, Santos MA, Zanetti ML. Adherence to diabetes mellitus treatment and sociodemographic, clinical and metabolic control variables. Acta Paul Enferm. 2015;28(4):315-22. doi: 10.1590/1982-0194201500054

40. Wong MC, Wu CH, Wang HH, Li HW, Hui EM, Lam AT, et al. Association between the 8-iten Morisky medication adherence scale (MMAS-8) score and glycaemic contyrol among Chinese diabetes patients. J Clin Pharmacol. 2015;55(3):279-87. doi: 10.1002/jcph.408 